\title{
The Role of ACE I/D Gene Mutations in The Etiology of Buergers's Disease
}

\author{
Filiz Ozen ${ }^{1}$, Nadir Kocak², Atilla Orhan ${ }^{3}$ Taha T. Bekci ${ }^{4}$
}

${ }^{1}$ Goztepe Education and Research Hospital, Department of Genetic, Istanbul

${ }^{2}$ Konya Education and Research Hospital, Department of Genetic, Konya

${ }^{3}$ Konya Education and Research Hospital, Department of Cardiovascular Surgery, Konya

${ }^{4}$ Konya Education and Research Hospital, Department of Pulmonary Medicine, Konya

Eur J Basic Med Sci 2012;2(1):6-11

Received: 25.02.2011

Accepted: 09.03.2012

Correspondence (Yazıșma Adresi):

Taha T. Bekci, M.D.

Konya Education and Research Hospital, Department of Pulmonary Medicine, Meram Yeniyol, 42100, Meram-KonyaTURKEY

E-mail : doktortaha@konyaea.gov.tr

Phone : +905333787676

Fax : +903323222508

\begin{abstract}
Thromboangiitis obliterans (TAO), which is also known as Buerger's disease, is a disease characterized by segmental inflammation together with vasoactive phenomena in the arteries and veins of the extremities. In the present study, the relationship between angiotensin-converting enzyme (ACE) insertion/deletion (I/D) gene mutations, which is known to be involved in vasodysfunction, and TAO was determined. Because of this relationship, it was aimed to determine whether the distribution of angiotensin-converting enzyme (ACE) insertion / deletion (I / D) gene mutations in patients with Thromboangiitis obliterans (TAO) is different from healthy subjects in the control group. Eighty patients who were previously diagnosed with TAO were included in the study. The patients were determined based on Olin's criteria. The control group consisted of 88 healthy volunteers. DNA isolation was performed by venous blood from the patients in both groups. The DNAs were amplified via polymerase chain reaction $(P C R)$ using appropriate primers, the amplicons were eluted by running in $1 \%$ agarose gel, and defined via staining. In addition to the significant difference between the patient and control groups in terms of age and smoking due to the selection criteria (Olin's criteria), a statistically significant difference was also determined between the groups in terms of the distribution of the ACE I/D gene polymorphism. The significant difference between groups with respect to the ACE I/D polymorphism, together with the smokinglike effects of $A C E$ on the cardiovascular system, reveal a consequence which should not be neglected.
\end{abstract}

Key words: Polymerase chain reaction, angiotensin, mutation, genotype 


\section{Buerger Hastalığının Etyolojisinde ACE I/D Gen Mutasyonlarının Rolü \\ ÖZET}

Burger hastalığı olarakta bilinen tromboanjitis oblitarans ekstremitelerin arter ve venlerinde vazoaktif fenomenler ile segemental inflamasyonun birlikte görülmesiyle karakterize bir hastalıktır. Bu çalıșmada, vazodisfonksiyon olușumuna katılan anjiotensin-konverting enzim (ACE) insersiyon/delesyon (I/D) gen mutasyonları ile tromboanjitis oblitarans (TAO) arasındaki ilișkiyi belirlemeye çalıștık. Bu ilișki nedeniyle, tromboanjitis obliteranslı (TAO) hastalarda anjiotensin-konverting enzim (ACE) insersiyon/delesyon (I/D) gen mutasyonlarının dağılımının control grubundaki sağlıklı bireylerden farklı olup olmadığını belirlemeye amaçladık. Önceden TAO teșhisi konulmuş seksen hasta çalıșmaya dahil edildi. Bu hastalar Olin's kriterleri temel alınarak belirlendi. Kontrol grubu 88 gönüllü sağlıklı bireyden olușmaktaydı. DNA izolasyonu her iki gruptada venzö kandan yapıldı. DNA'lar uygun primerler kullanılarak polimeraz zincir reaksiyonu (PZR) yoluyla çoğaltıldı. Amplikonlar agaroz jelde yürütülerek ayrıștırıldı, boyanarak belirlendi. Seçim kriterlerine (Olin's kriterleri) bağlı olarak yaș ve sigara içimi açısından hasta ve control grubu arasında önemli farklılıklar görülmesine ek olarak ACE I/D gen polimorfizimlerinin dağılımı açısındanda istatisiksel olarak önemli farklar bulunmuștur. Kardiyovasküler sistem üzerinde ACE'nin sigara içimine benzer etkileri ile birlikte ACE I/D polimorfizmi açısından iki grup arasındaki bu önemli fark ihmal edilmemesi gereken bir sonuç ortaya çıkarmaktadır.

Anahtar Kelimeler: Polimeraz zincir reaksiyonu, Anjiotensin, mutasyon, genotip

\section{INTRODUCTION}

Thromboangiitis obliterans (TAO), also called Buergers's disease, is a vaso-occlusive inflammatory disease involving small and medium arteries or veins in the upper and lower extremities (1-3). TAO was first defined in 1908 by Buerger (4). The diagnostic criteria of TAO, which was determined in 1998 by Shionoya, were revised in 2000 by Olin $(4,5)$. The frequency of TAO varies according to the regions and the differences in the diagnostic methods. While TAO is relatively rare in western Europe $(0.5 \%-5.6 \%$ of peripheral arterial diseases), it is common among Ashkenazi Jews living in Israel (80\% of peripheral arterial diseases), whereas. The prevalence of TAO, which was determined to be $104 / 100.000$ in 1947 in the US, has dec-reased to $12.6 / 100.000$ in $1986(6,7)$.
Although the pathology of TAO has not been clearly elucidated, smoking is considered the leading etiologic factor. In addition to the toxic, carcinogenic, and mutagenic molecules, it is known that cigarettes also contain free radicals and reactive oxygen species (ROS) (8-10). Some of the water-soluble components of cigarettes lead to the production of superoxide anion $\left(\mathrm{O}^{-}\right)$, hydrogen peroxide ( $\mathrm{H} 2 \mathrm{O} 2)$, and reactive hydroxyl radicals ( $\mathrm{HO})$, thus causing cellular damage (11-14). It has been reported that the glutathione level is decreased in smokers and this has led to a decrease in antioxidant capacity (15). Furthermore, smoking, by accelerating the passage of polymorphonuclear (PMN) leukocytes from the bone marrow into the circulation, accelerates inflammatory processes (16).

Impairment of endothelium-dependent vasorelaxation has been demonstrated in patients with TAO. While an increase in response to intra-arterial acetylcholine is expected in patients with TAO compared to normal subjects, non-endothelial mechanisms of vasodilatation are not impaired. Unlike many autoimmune vascular diseases, no signs of systemic inflammatory responses, such as an increased erythrocyte sedimentation rate and $\mathrm{C}$-reactive protein level, are generally encountered in TAO (17).

Angiotensin-converting enzyme (ACE) is a zinc metalloprotease that exists on the surface of endothelial and epithelial cells. ACE converts angiotensin I, which is an inactive decapeptide, into angiotensin II, an active octapeptide. Angiotensin II is a potent vasoconstrictor (18$20)$. ACE plays a key role in the production of angiotensin II (21). Angiotensin II, which is a member of the reninangiotensin system, is a potent vasoconstrictor that also affects the inflammatory processes (22-24). In addition to the systemic rennin-angiotensin system, the local renninangiotensin system contributes to cardiovascular inflammation (25). It has been observed that angiotensin II is effective in almost all steps of the inflammatory response, such as leukocyte activity, leukocyte-endothelium interaction, vascular permeability, and tissue remodeling (26). It has been demonstrated that angiotensin II led to leukocyte endothelium interactions in the post-capillary venules by increasing the ROS (27). This effect can be inhibited by the use of antioxidants (28). While ACE is effective in increasing the angiotensin level, it inhibits the release of vasodilators, such as nitric oxide (NO) and prostacyclin, from the endothelium by increasing the level of bradykinin (29).

The ACE gene is localized on chromosome 17 and a to- 
Table 1. Characteristics of the patients with thromboangiitis obliterans (TAO) and the control group

\begin{tabular}{lllr}
\hline & $\begin{array}{l}\text { Control group } \\
(\text { Mean } \pm S D)\end{array}$ & $\begin{array}{l}\text { TAO } \\
(\text { Mean } \pm S D)\end{array}$ & $p^{*}$ \\
\hline Age (years) & $42 \pm 13.02$ & $33.84 \pm 5.06$ & $<0.001$ \\
Body Weight $(\mathrm{kg})$ & $74.48 \pm 8.64$ & $76.62 \pm 9.46$ & 0.824 \\
BMl (kg/m2) & $27.20 \pm 3.29$ & $26.43 \pm 2.76$ & 0.438 \\
\hline
\end{tabular}

- One-way ANOVA and Turkey, TAO: Thromboangiitis obliterans; BMI: Body mass index; SD: Standard deviation

tal of 78 polymorphisms have been determined (30). The ACE insertion (I) deletion (D) polymorphism is the most studied among these polymorphisms (31). The presence or absence of a 287-base pair sequence in intron 16 of the ACE gene leads to these polymorphisms $(30,32,33)$. While the insertions observed at this site in the ACE gene decrease the expression of ACE, the deletions increase its expression. Compared to II homozygotes, DD homozygotes express $65 \%$ more ACE, whereas ID heterozygotes express $31 \%$ more ACE (32). An association between ACE I/D polymorphisms with coronary heart disease, ventricular hypertrophy, and myocardial infarction was reported (34-40). Furthermore, it was determined that the release of endothelial bradykinin and NO decreased in the subjects carrying the DD genotype $(41,42)$.

Since TAO is a disease characterized by inflammation and thrombotic attacks resulting in vaso-occlusion, the ACE and thereby its mutations have been considered to have an effect in the pathogenesis of the disease. Thus, in the present study it was aimed to determine the distribution of ACE I/D polymorphisms in patients with TAO.

\section{MATERIALS AND METHODS}

Eighty patients (74 men, 6 women) who were diagnosed with TAO in Konya Education and Research Hospital, and Goztepe Konya Education and Research Hospital between 2008 and 2009, and 88 (46 men, 42 women) healthy subjects were enrolled in the present study. The patients and the healthy control subjects were randomly selected. The age, height, weight, and body mass indexes (BMI) of the patient and control groups were assessed.

TAO was diagnosed in accordance with Olin's criteria (43), as follows: 1 ) onset of symptoms before 45 years of age; 2 ) history of smoking at the time of diagnosis or up to recent times; 3 ) presence of distal extremity ischemia (infrapopliteal or infrabrachial), indicated by claudication, rest pain, ischemic ulcers, and gangrene; 4) absence of an autoimmune or connective tissue disease, and also hypercoagulability states, or diabetes; 5) undetermined emboli originating from a proximal source via echocardiography or cardiography; and 6 the presence of permanent arteriographic findings in the clinically involved and noninvolved extremities.

\section{Determination of Gene Mutations}

DNA was isolated from the blood samples using Standard procedures (salting out).(44) The II, ID, and DD genotypes were detected by PCR according to the method of Lindpaintner et al [45] with some modifications. The insertion and deletion alleles of the ACE gene were identified by using a set of oligonucleotide primers flanking the polymorphic site in intron 16 . The final volume of the PCR mix was $20 \mathrm{ml}$, containing $50 \mathrm{ng}$ DNA as template and 1X PCR buffer (Gibco), $1.3 \mathrm{mmol} / \mathrm{l} \mathrm{MgCl} 2,200 \mathrm{mmol} / \mathrm{l}$ dNTPs, $20 \mathrm{pmol}$ primer mix and $0.35 \mathrm{U}$ Taq polymerase in a thermal cycler (Bioder/Thermal Blocks SP Cycler, Tokyo, Japan). The thermocycling procedure was completely identical to the method of Lindpaintner et al [45]. The result of amplification was a $319 \mathrm{bp}$ and a $597 \mathrm{bp}$ amplicon for the $D$ and I alleles respectively.

In the post-PCR analyses, $10 \mathrm{ml}$ of PCR product was loaded onto a $3 \%$ agarose gel. Fragments were visualised using etidium brominde staining and UV transillumination.

\section{Statistical Analysis}

SPSS 15.0 package program was used for the analysis of data. The Kolmogorov-Smirnov test was used in order to test the normal distribution, and one-way ANOVA test was used to determine the homogeneity of data. One-way ANOVA and Tukey tests was used for parametric comparisons. Independent chi-square test was used for non-parametric comparisons. A p value $<0.05$ was considered as statistically significant.

\section{Ethical Approval}

The study was approved by the Ethics Committee of Konya Selcuk University Meram Faculty of Medicine in Turkey.

\section{RESULTS}

When the characteristic features of the control and pa- 
Table 2. The smoking rates and the gender distribution of the control group and the patients with thromboangiitis obliterans (TAO)

\begin{tabular}{|c|c|c|c|}
\hline & $\begin{array}{l}\text { Control Group } \\
n(\%)\end{array}$ & $\begin{array}{l}\text { TAO } \\
n(\%)\end{array}$ & $p^{*}$ \\
\hline \multicolumn{4}{|l|}{ Smoking } \\
\hline Yes & $32(36.4)$ & $80(100.0)$ & $<0.001$ \\
\hline No & 56 (63.6) & $0(0.0)$ & \\
\hline \multicolumn{4}{|l|}{ Gender } \\
\hline Male & $46(52.27)$ & 74 (92.5) & $<0.001$ \\
\hline Female & $42(47.73)$ & $6(7.5)$ & \\
\hline
\end{tabular}

${ }^{*}$ Chi-square analysis was used

tient groups, such as age, weight, and body mass index (BMI), were compared, a significant difference existed between the control and patient groups with respect to age $(42 \pm 13.02$ vs. $33.84 \pm 5.06$ years, respectively) which was attributed to the selection criteria (Olin criteria; $\mathrm{p}<0.05$ ) (Table 1). No difference was observed between the control and patient groups with respect to body weight $(74.48 \pm 8.64$ vs. $76.62 \pm 9.46 \mathrm{~kg}$, respectively), and BMI $(27.20 \pm 3.29$ vs. $26.43 \pm 2.76 \mathrm{~kg} / \mathrm{m} 2$, respectively; $p>0.05$ ) (tablo 1). The smoking rate was significantly higher in the patient group (100\%) compared to the control group (43.2\%), $(\mathrm{p}<0.05)$ (Table 2$)$.

A significant difference existed between the groups with respect to the distribution of ACE I/D gene polymorphisms $(p<0.05)$. This difference was particularly remarkable in the DD genotype. According to the ACE I/D gene polymorphisms, the distribution of the genotypes in the control group was $20(22.7 \%)$ for the II allele, it was 54 (61.4\%) for the ID allele, and it was 14 (15.9\%) for the DD allele, whereas the distribution of the genotypes in the patient group was $26(32.5 \%)$ for the II allele, it was $24(30 \%)$ for the ID allele, and $30(37.5 \%)$ for the DD allele. When the allele distribution of the control and the patient groups was examined, similar rates were determined for allele I (94 [53.41\%] and 76 [47.5\%], respectively) and allele D (82 [46.59\%] and 84 [52.50\%], respectively) (Table 3 ).

\section{DISCUSSION}

Since smoking and angiotensin II have similar effects on the vascular endothelium, it was considered that both might have a synergistic effect in the pathogenesis of TAO. In the present study, the ACE DD genotype was significantly higher in the patient group $(37.5 \%)$ compared to the control group (15.9\%), thus supporting this notion. It was observed that there is a homozygous mutant (ACE DD) genetic inheritance in the patient group that should be taken into consideration. This condition, which leads to an increase in the ACE enzyme activity by approximately $65 \%$, indirectly leads to an increase in the angiotensin II levels (32). Thus, while ACE exhibits a vasoactive feature via bradykinin, it becomes effective on the vascular endothelium accelerating the oxidative and inflammatory processes $(11,12,29)$. It is probable for the pathologic processes to be accelerated with the additive synergistic effects of smoking.

Although the pathology of TAO has not been clearly elucidated, smoking is considered the leading etiologic factor. In addition to the toxic, carcinogenic, and mutagenic molecules, it is known that cigarettes also contain free radicals and reactive oxygen species (ROS) (8-10). Some of the water-soluble components of cigarettes lead to the production of superoxide anion $\left(\mathrm{O}^{-}\right)$, hydrogen peroxide ( $\mathrm{H} 2 \mathrm{O} 2)$, and reactive hydroxyl radicals (HO), thus causing cellular damage (11-14). It has been reported that the glutathione level is decreased in smokers and this has led to a decrease in antioxidant capacity (15). Furthermore, smoking, by accelerating the passage of polymorphonuclear (PMN) leukocytes from the bone marrow into the circulation, accelerates inflammatory processes (16).

A history of smoking as a selection criterion presented a remarkable difference between the patient $(100 \%)$ and the control (36.4\%) groups with respect to smoking. While the rate of female smokers in the control group was $13.6 \%$; the rate increased to $59.1 \%$ for male smokers. This corroborates the suggestion that Buerger's disease is predominantly a disease of males. Nevertheless, only $7.5 \%$ of the patient group consisted of females. These results are in agreement with the characteristic features of the disease.

The significant difference between groups with respect to the ACE I/D polymorphism, together with the smoking-like effects of ACE on the cardiovascular system, reveal a consequence which should not be neglected. The lack of the the determining of distribution of the ACE I / D polymorphisms in TAO patients in literature has prevented us to compare our results with the different data. Despite to the our study group were limited and exclusion of environmental factors such as smoking was not achieved, we hope that our the results to be leading 
Table 3. Genotype and allele frequencies of angiotensin-converting enzyme (ACE) I/D polymorphism in the control group and patients with thromboangiitis obliterans (TAO)

\begin{tabular}{lccc}
\hline Allele (C677T) & $\begin{array}{c}\text { Control group } \\
n(\%)\end{array}$ & $\begin{array}{c}\text { Patients with TAO } \\
n(\%)\end{array}$ & $p^{*}$ \\
\hline II & $20(22.70)$ & $26(32.50)$ & \\
ID & $54(61.40)$ & $24(30.00)$ & \\
DD & $14(15.90)$ & $30(37.50)$ & 0.012 \\
I & $94(53.41)$ & $76(47.50)$ & \\
$D$ & $82(46.59)$ & $84(52.50)$ & \\
\hline
\end{tabular}

${ }^{*}$ Chi-square analysis was used

for the next studies. ACE I / D polymorphisms, especially because of its relationship with ACE inhibitors should be considered in terms of pharmacogenetics. Finding of the similar results with more extensive studies be performed in future in patients with TAO will be able to contribute to the pharmacogenetic studies taking into account the ACE I / D polymorphisms.

The significant difference between groups with respect to the ACE I/D polymorphism, together with the smoking-like effects of ACE on the cardiovascular system, reveal a consequence which should not be neglected. The present study may add to a better understanding of the pathogenesis of TAO.

\section{REFERENCES}

1. Buerger L. Thromboangiitis obliterans: a study of the vascular lesions leading to presenile gangrene. Am J Med Sci 1952; 136: 567-80.

2. Buerger $L$. The circulatory disturbance of the extremities: including gangrene, vasomotor and trophic disorders. Philadelphia, Saunders, 1924.

3. Olin JW, Young JR, Graor RA, Ruschhaupt WF, Bartholomew $J R$. The changing clinical spectrum of thromboangiitis obliterans (Buerger's disease). Circulation 1990; 82: 3-8.

4. Shionoya S. Diagnostic criteria of Buerger's disease. Int J Cardiol 1998; 1:243-5.

5. Olin JW. Thromboangiitis obliterans (Buerger's disease). N Engl J Med 2000; 343: 864-9.

6. Idem. The rise and fall and resurgence of thromboangiitis obliterans (Buerger's disease). Acta Pathol Jpn 1989; 39: 153-8.

7. Idem. Thromboangiitis obliterans (Buerger's disease) in women. Medicine (Baltimore) 1987; 66: 65-72.

8. Hoffman D, Hoffmann I. The changing cigarette, 19501995. J Toxicol Environ Health 1997; 50: 307-64.

9. Hoffmann D, Wynder EL. Chemical constituents and bioactivity of tobacco smoke. In Tobacco: A Major International Hazard, No 74; Zaridze, DG, Peto, R, Eds; International Agency for Research on Cancer, IARC Scientific Publications: Lyon, France, 1986; 145-66.

10. Vineis $P$, Alavanja $M$, Buffler $P$, Fontham $E$, Franceschi $S$, Gao YT, Gupta PC, Hackshaw A, Matos E, Samet J, Sitas F, Smith J, Stayner L, Straif K, Thun MJ, Wichmann HE, Wu $A H$, Zaridze D, Peto R, Doll R. Tobacco smoke and cancer: recent epidemiological evidence. J Natl Cancer Inst 2004; 96: 99-105.

11. Pryor WA, Curch DF, Evans MD, Rice WY, Hayes JR. A comparison of the free radical chemistry of tobacco-burning cigarettes and cigarettes that only heat tobacco. Free Radic Biol Med 1990; 8: 275-79.

12. Environmental Protection Agency. Respiratory Health Effects of Passive Smoking: Lung Cancer and Other Disorders; EPA Publications: Washington DC, USA, 1992.

13. Heidrich J, Wellmann J, Heuschmann PU, Kraywinkel K, Keil U. Mortality and morbidity from coronary heart disease attributable to passive smoking. Eur Heart J 2007; 28: 2498-502.

14. Valavanidis A, Vlachogianni T, Fiotakis K. Tobacco Smoke: Involvement of reactive oxygen species and stable free radicals in mechanisms of oxidative damage, carcinogenesis and synergistic effects with other respirable particles. Int J Environ Res Public Health 2009; 445-62.

15. Glantz SA, Parmley WW. Passive smoking and heart disease: mechanisms and risk. JAMA 1996; 273:1047-53.

16. Terashima T, Klut ME, English D, et al. Cigarette smoking causes sequestration of polymorphonuclear leukocytes released from the bone marrow in lung microvessels. Am J Respir Cell Mol Biol 1999; 20:171-7.

17. Makita S, Nakamura M, Murakami H, Komoda K, Kawazoe $K$, Hiramori K. Impaired endothelium-dependent vasorelaxation in peripheral vasculature of patients with thromboangiitis obliterans (Buerger's disease). Circulation 1996; 94: Suppl II: 211-15.

18. Erdos EG, Skidgel RA. The angiotensin l-converting enzyme. Lab Invest 1987; 56: 345-48.

19. Griendling KK, Murphy TJ, Alexander RW. Molecular biology of the renin-angiotensin system. Circulation 1993; 87:1816-28.

20. Samani NJ, Swales JD. Molecular biology of the vascular rennin angiotensin system. Blood Vessels 1991; 28: 210-6.

21. Rigat B, Hubert C, Alhenc-Gelas F, Cambien F, Corvol P, Soubrier F. An insertion/deletion polymorphism in the angiotensin l-converting enzyme gene accounting for half the variance of serum enzyme levels. J Clin Invest 1995; 86: $1343-6$.

22. Carey RM, Siragy HM. Newly recognized components of the rennin-angiotensin system: potential roles in cardiovascular and renal regulation. Endocr Rev 2003; 24: 261-71.

23. Cheng ZJ, Vapaatalo H, Mervaala E. Angiotensin II and vascular inflammation. Med Sci Monit 2005; 11: 194-205.

24. Ferrario $C M$, Strawn WB. Role of the renin-angiotensin 
system and pro-inflammatory mediators in cardiovascular disease. Am J Cardiol 2006; 98: 121-28.

25. Paul M, Poyan Mehr A, Kreutz R. Physiology of local reninangiotensin systems. Physiol Rev 2006; 86: 747-803.

26. Orth T, Allen J, Wood JG, Gonzalez NC. Plasma from conscious hypoxic rats stimulates leukocyte-endothelial interactions in normoxic cremaster venules. J Appl Physiol 2005; 99: 290-7.

27. Suzuki H, Frank GD, Utsunomiya H, Higuchi S, Eguchi $S$. Current understanding of the mechanism and role of ROS in angiotensin II signal transduction. Curr Pharm Biotechnol 2006; 7: 81-6.

28. Wood JG, Johnson JS, Mattioli LF, Gonzalez NC. Systemic hypoxia promotes leukocyte-endothelial adherence via reactive oxidant generation. J Appl Physiol 1999; 87: 1734-40.

29. Soubrier F, Hubert $C$, Testut $P$, Nadaud S, Alhenc-Gelas $F$, Corvol P. Molecular biology of the angiotensin I converting enzyme, I: biochemistry and structure of the gene. $J$ Hypertens 1993; 11: 471-6.

30. Baudin B. New aspect on angiotensin-converting enzyme: from gene to disease. Clin Chem Lab Med 2002; 40: 25665.

31. Rieder MJ, Taylor SL, Clark AG, Nickerson DA. Sequence variation in the human angiotensin converting enzyme. Nat Genet 1999; 22: 59-62.

32. Rigat B, Hubert $C$, Alhenc-Gelas F, Cambien F, Corvol P, Soubrier F. An insertion/deletion polymorphism in the angiotensin-1-converting enzyme gene accounting for half the variance of serum enzyme levels. J Clin Invest 1990; 86: 1343-6.

33. Prasad A, Narayanan S, Waclawiw MA, Epstein N, Quyyumi $A A$. The insertion/deletion polymorphism of the angiotensin-converting enzyme gene determines coronary vascular tone and nitric oxide activity. J Am Coll Cardiol 2000; 36: 1579-86.

34. Kitsios G, Zintzaras E. ACE (I/D) polymorphism and response to treatment in coronary artery disease: a comprehensive database and meta-analysis involving study quality evaluation. BMC Medical Genetics 2009; 10: 5060.

35. Cambien F, Poirier $O$, Lecerf L, Evans A, Cambou JP, Arveiler $D$, et al. Deletion polymorphism in the gene for angiotensin converting enzyme is a potent risk factor for myocardial infarction. Nature 1992; 359: 641-4.
36. Marian $A J, Y u Q$ Workman $R$, Greve $G$, Roberts $R$. Angiotensin converting enzyme polymorphism in hypertrophic cardiomyopathy and sudden cardiac death. Lancet 1993; 342: 1085-6.

37. Butler $R$, Morris $A D$, Struthers $A D$. Angiotensin-converting enzyme gene polymorphism and cardiovascular disease. Clin Sci 1997; 93: 391-400.

38. Alvarez $R$, Reguero JR, Batalla A, Iglesias-Cubero $G$, Cortina A, Alvarez $V$, et al. Angiotensin-converting enzyme and angiotensin II receptor 1 polymorphisms: association with early coronary disease. Cardiovasc Res 1998; 40: 375-9.

39. Alvarez $R$, Terrados $N$, Ortolano $R$, Iglesias-Cubero $G$, Reguero JR, Batalla $A$, et al. Genetic variation in the rennin-angiotensin system and athletic performance. Eur J Appl Physiol 2000; 82: 117-20.

40. Agerholm-Larsen B, Nordestgaard BG, Tybjaerg-Hansen A. $A C E$ gene polymorphism in cardiovascular disease: metaanalyses of small and large studies in whites. Arterioscler Thromb Vasc Biol 2000; 20: 484-92.

41. Buikema H, Pinto YM, Rooks G, Grandjean JG, Schunkert $H$, van Gilst WH. The deletion polymorphism of the angiotensin-converting enzyme gene is related to phenotypic differences in human arteries. Eur Heart $J$ 1996; 17: 787-94.

42. Chadwick IG, O'Toole L, Morice AH, Yeo WW, Jackson PR, Ramsay LE. Pressor and hormonal responses to angiotensin I infusion in healthy subjects of different angiotensinconverting enzyme genotypes. J Cardiovasc Pharmacol 1997; 29: 485-9.

43. Olin JW. Thromboangiitis obliterans (Buerger's disease). In: Rutherford RB, editor. Vascular surgery. 6th ed. Vol. 1, Philadelphia: W. B. Saunders; 2005; 404-19.

44. Miller SA, Dykes DD, Polesky HF. A simple salting out procedure for extracting DNA from human nucleated cells. Nucleic Acids Res 1988;16:1215.

45. Lindpaintner $K$, Pfeffer MA, Kreutz R, Stampfer MJ, Grodstein F, LaMotte F, Buring J, Hennekens CH. A prospective evaluation of an angiotensinconverting enzyme gene polymorphism and the risk of ischemic heart disease. N Engl J Med 1995;332:706-11. 